\title{
Research on Energy Consumption of Traditional Natural Villages in Transition: A Case Study in Zhejiang Province
}

\author{
Meiyan Wang1,2*, Shenglan Huang2, Xinxin Lin', Didit Novianto1, Liyang Fan ${ }^{3}$, Weijun Gao', \\ Zu Wang 4 \\ ${ }^{1}$ Environmental Engineering, University of Kitakyushu, Kitakyushu, Japan \\ ${ }^{2}$ School of Landscape and Architecture, Zhejiang A\&F University, Lin'an, China \\ ${ }^{3}$ Nikken Sekkei Research Institute, Osaka, Japan \\ ${ }^{4}$ School of Architecture \& Civil Engineering, Zhejing University, Hangzhou, China \\ Email: "wangmeiyan0606@163.com
}

Received 30 November 2015; accepted 26 January 2016; published 29 January 2016

Copyright (C) 2016 by authors and Scientific Research Publishing Inc.

This work is licensed under the Creative Commons Attribution International License (CC BY).

http://creativecommons.org/licenses/by/4.0/

(c) (i) Open Access

\begin{abstract}
Traditional agriculture is in the direction of increasing integration of the primary industry, secondary industry, and tertiary industry in Zhejiang province. A survey was undertaken on energy consumption of traditional natural villages by taking Anji Ligeng village for an example. This paper firstly studied rural buildings, rural family structure, occupants' activity and the usage of household appliances in the form of a questionnaire. Then, the household energy resource structure and energy consumption structure were analyzed and compared with other surveys. The results show that, the electric energy consumption was $6 \mathrm{kWh} /\left(\mathrm{m}^{2} \cdot \mathrm{a}\right)$, which was far less than urban residential household. In rural household energy resource structure, the proportion of non-commercial energy resource was higher than commercial energy resource. Firewood accounted for $83 \%$, electricity for $12 \%$, LPG for $3 \%$ and solar energy for $2 \%$. In building energy consumption structure, cooking and hot water took up $33 \%$, appliances $31 \%$, lighting $20 \%$, heating $12 \%$, cooling $4 \%$. In all influential factors, frequently used area, number of air conditioner per household and building function were obviously correlated with energy consumption; income, building shape factor and window to wall area ratio had no correlation with energy consumption in the low energy consumption area.
\end{abstract}

\section{Keywords}

Natural Village, Rural Building, Energy Resource, Energy Consumption Structure, Influential

\footnotetext{
${ }^{*}$ Corresponding author.
}

How to cite this paper: Wang, M.Y., Huang, S.L., Lin, X.X., Novianto, D., Fan, L.Y., Gao, W.J. and Wang, Z. (2016) Research on Energy Consumption of Traditional Natural Villages in Transition: A Case Study in Zhejiang Province. Energy and Power Engineering, 8, 34-50. http://dx.doi.org/10.4236/epe.2016.81004 


\section{Factor}

\section{Introduction}

Since the Reform and Opening-up policy was initiated in 1978, influenced by the tide of world economic globalization, China's rural areas are experiencing unprecedented rapid development, especially in the countryside along the coast areas where the economy developed rapidly. In 2010 the Chinese government launched the "New Rural Construction" campaign, in order to improve the rural living standards. Under the dual stimulation of politics and economy, rural building energy consumption increased from $80 \mathrm{kgce}$ in 2000 to $246 \mathrm{kgce}$ in 2012 [1].

By the radiation and drive of the China Yangtze River Delta region, the Engel coefficient of rural residents in Zhejiang province dropped from 50.4 in 1995 to 37.7 in 2012 (Figure 1), which indicated that the rural living standards reached the rich level. In recent years, Zhejiang government put forward the "one product for one village, one industry for one town" development plan, and then "Farmhouse", "E-commerce village" grew up. Traditional agriculture is in the direction of the integration of the primary industry, secondary industry, and tertiary industry in Zhejiang province. With the rural production and living patterns changing, rural household energy structure and energy consumption have had a huge change. The consumption of coal reduced; electricity and LPG increased fast; firewood, straw and other biomass substantially reduced [1]-[3] (Figure 1). The rapid development of economic and the tremendous change of rural energy structure have brought great energy pressure. The aim of this paper is to explore the features of rural household energy consumption in traditional natural rural villages by taking Anji Ligeng village for an example, and analyze its influential factors.

\section{Previous Studies}

Since the late 1980s, domestic and foreign scholars have done a lot of research on rural energy consumption in China [4]-[6], which were mainly based on the statistical data published by the government, or a wide range of questionnaire. Wang et al. analyzed the main energy sources used in rural areas and the end-used energy consumption according to the 30 provinces energy consumption statistics [7]. Guo et al. studied rural energy consumption level in 1996 from four sectors-lighting, cooking and hot water, heating and household appliances, by using both macro- and micro-approaches [8]. Tsinghua University has undertaken a large-scale survey in rural areas from 2006 to 2008, and compared the difference of rural energy consumption between the North and South rural areas [9].

In terms of the influences of energy consumption, the relationship between income and energy consumption has been studied. Wang et al. believes that income is related to electricity consumption, but less related to com-

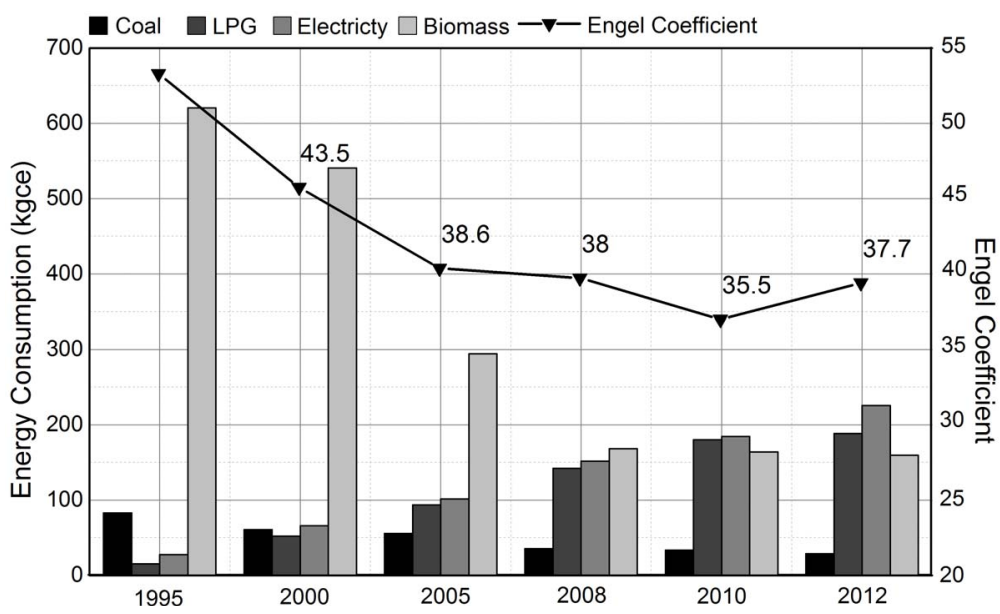

Figure 1. Rural energy consumption and Engel coefficient in Zhejiang province (1995-2012). 
mercial energy consumption [10]; some other researches reveals the relationship between them [8] [11]. In other ways, such as climate, terrain, education, consuming behavior, appliances, building area are also discussed [10]-[14].

Previous researches have revealed the nationwide characteristics of energy structure in China from macro aspects, and it was very clear that the energy consumption in Northern China is higher than Southern. However, they are too general and not precise enough. Some scholars focus on the regional areas. Li et al. surveyed the rural energy resources in Zhangziying town near Beijing [15]. Yutaka et al. took a survey about the energy consumption in winter especial the usage of stoves [16]. Wu et al. investigated 30 households in Jinzhou area and analyzed the heating, cooking, lighting and other end-used energy consumption [17]. Besides the study of rural energy consumption, some scholars also analyzed the indoor environment, carbon dioxide emissions and other aspects problems [18]-[21]. These researches explored the concrete conditions in Northern China, but studies in Southern China are lacking [22]-[24]. And all these results will be compared with our study later on. Moreover, we found that above-mentioned researches were from the point of view of geographic position or climate, but lacking from different types in rural industrial structures.

\section{Survey Methodology}

\subsection{Overview of the Study Village}

The Engel coefficient of Anji county in 2013 is 32.8\%, which belongs to affluence level [25]. Ligeng village which we studied is located in Anji country of Zhejiang province, with the longitude of E30 45'59.61", latitude of $\mathrm{N} 119^{\circ} 29^{\prime} 37.47^{\prime \prime}$, and altitude of $263 \mathrm{~m}$. The coldest monthly average temperature is $-8.5^{\circ} \mathrm{C}$, the hottest monthly average temperature is $38.7^{\circ} \mathrm{C}$, with an annual average temperature of around $16.6^{\circ} \mathrm{C}$. Ligeng village is next to shimen village, Zhongshan village, Dayinshan village and consists of three groups named Li Geng, Li Cun and Li Ming. It has 120 households, and more than 400 people. The village lies in a small valley, and is famous for cool and beautiful nature landscape that attracting lots of tourists every year to enjoy "Agritainment" in recent years.

\subsection{Sample Design and Investigation Method}

Sample size selection is crucial to the results of survey. If sample size is too large, it will cause the waste of manpower, material and financial resources. However, if the sample size is too small, it will affect the reliability of survey. The overall survey scale is between 100 and 1000, the appropriate sample volume of empirical judgment interval is $50 \%-20 \%$ [26]. The simple random sampling method was applied to collect the data, and we finally chose 49 household as the object of our survey, accounting for $40.8 \%$ of the total households in Ligeng village. Figure 2 shows the distribution of the samples which were uniformly distributed. The questionnaire survey was conducted from house to house. Since most farmers we surveyed were illiterate, the face-to-face interview was adopted to get more detailed data. The interviewers asked a set of questions and filled in the answers. We made a pre-survey in May 2014. In order to improve the reliability of the survey, we repeated our interview in September 2014 and July 2015.

\subsection{Questionnaire Design}

The types of household energy consumption include commercial energy (coal, LPG and electricity etc.) and non-commercial energy (firewood, straw, mash gas etc.) [1] [3]. The household energy utilization modes consist of five categories: cooking and hot water, heating, cooling, lighting, and household appliances [27]. The household energy consumption is related to the number of family members, rural buildings and energy usage habits. So the questionnaire we designed includes five aspects: family information, building information, energy usage, household appliances and human behavior (Table 1).

\section{Survey Results}

\subsection{Features of Households}

\subsubsection{Family Composition}

The family size we surveyed is 2 to 9 , and the average size is 4.6 persons per household. Three-generation family is very common, as high as $73.5 \%$. Five person in one family accounts for $44.9 \%$, with the mode of 2 (old couples)-2 (young parents)-1 (child). The ratio of migrant population working outside is very large, which is 


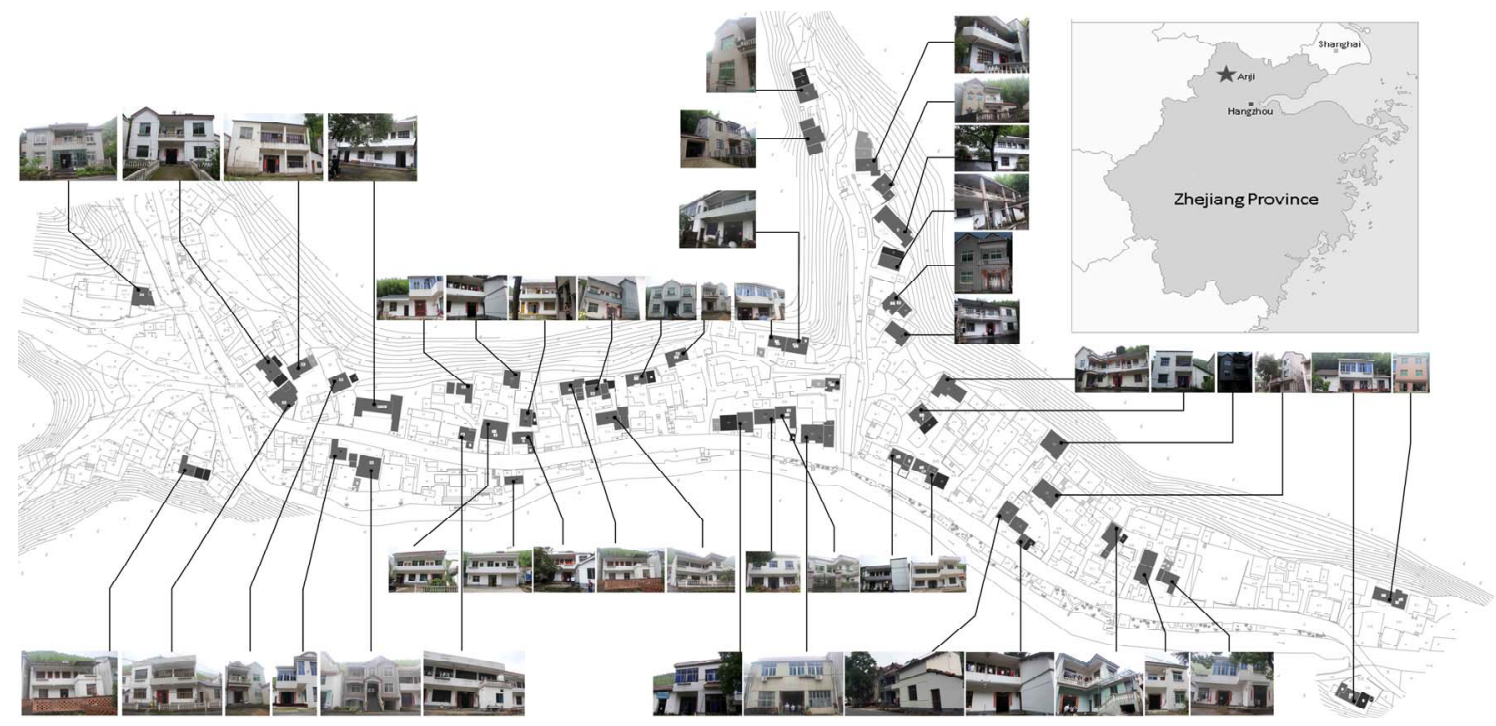

Figure 2. Plan of Ligeng village and distribution of samples.

Table 1. Questionnaire content.

\begin{tabular}{ll}
\hline Items & Main Content \\
\hline Household Information & $\begin{array}{l}\text { Family population, permanent population, age, cultural level, income etc. } \\
\text { Built time, layers, building orientation, building area, material and construction, shape coefficient, } \\
\text { window to wall ratio etc. }\end{array}$ \\
$\begin{array}{l}\text { Energy Consumption } \\
\text { Household Appliance }\end{array}$ & $\begin{array}{l}\text { Electricity consumption, usage of LPG, firewood and solar energy etc. } \\
\text { Human Behavior }\end{array}$ \\
\hline
\end{tabular}

about 53\%. They work in big cities or towns most of the year, and only return home during holidays which is about two months. Two permanent population family accounts for 59.2\%, most of them are over 50-aged elders and school aged children. In permanent population, the old people over the age of 50 years old is up to $73 \%$, and over 60 years old is $48 \%$. According to international standard, the ratio of people aged over 60 reaches to $10 \%$, it will be considered as an aging society. It shows that Ligeng village has a significant population aging characteristic (Figure 3, Figure 4).

\subsubsection{Household Income}

Most household income in Ligeng village is made up of two parts: one is from traditional agricultural production and processing, mainly includes high mountain tea, bamboo and bamboo products processing. The other part is from migrant labor working in cities, which has become the main source of household income. In recent years, with the development of rural tourism, some families began operating agritainment. Table 2 shows that the household annual income from $\$ 5000$ to $\$ 10,000$ accounts for $49 \%$, from $\$ 15,000$ to $\$ 20,000$ takes up $30 \%$.

\subsection{Rural Building Status}

\subsubsection{Built Time Building Form Layers}

Figure 5 shows the typical rural buildings built in different periods. The buildings which were built before the 1980s had been demolished or rebuilt. The existing buildings, built in 1980s and 1990s, account for 69\%, and 53\% were built in 1990s. Lots of buildings were rebuilt in different periods, and we can see different styles in one building.

Most rural buildings have two or three stories, and two-story buildings account for $88 \%$. Living room, dining 


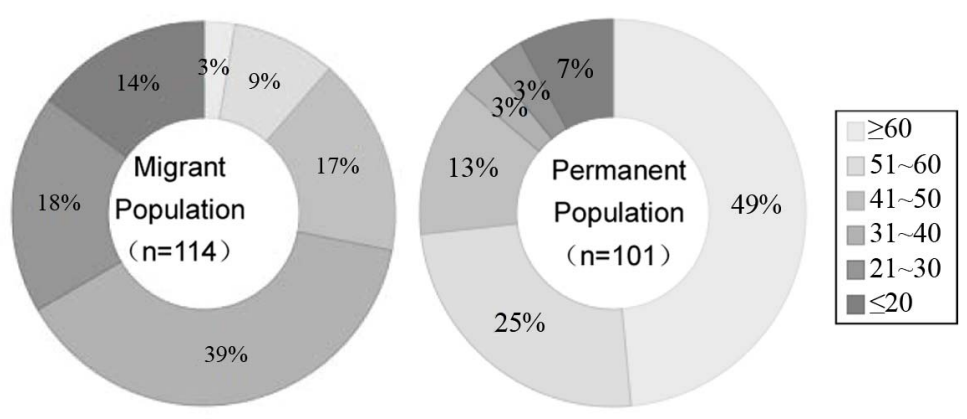

Figure 3. Age composition of migrant population and permanent population $(\mathrm{n}=215)$.

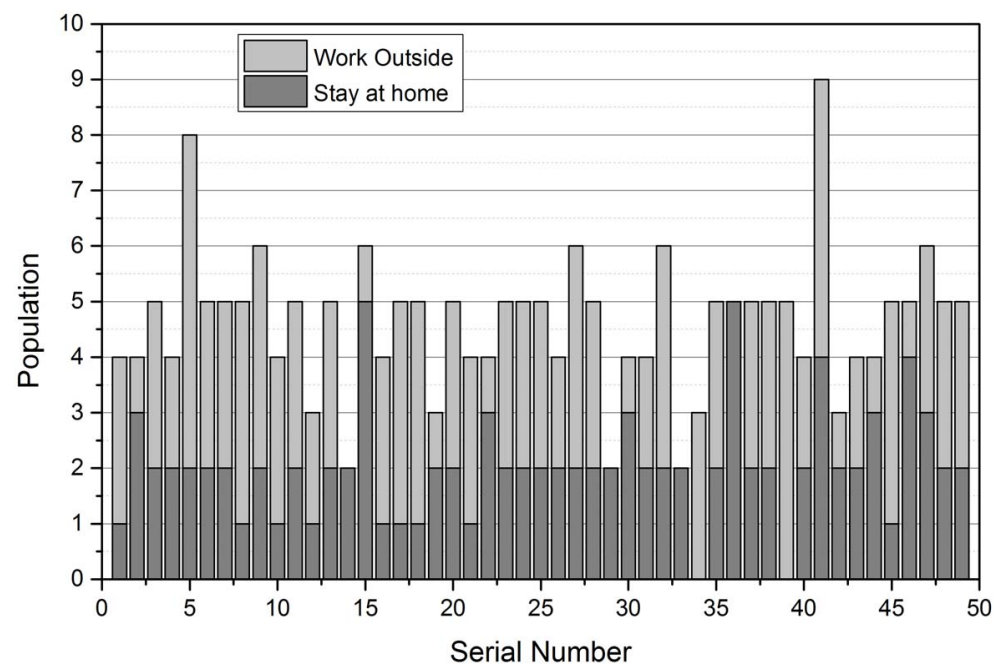

Figure 4. Family size and composition ( $n=49$ household).

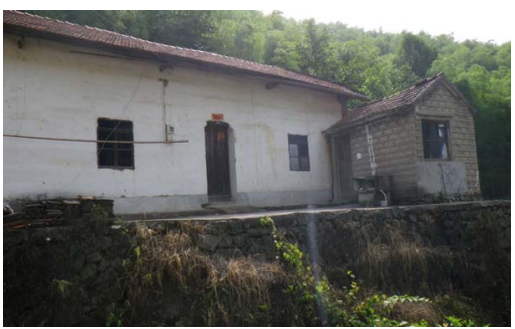

(a)

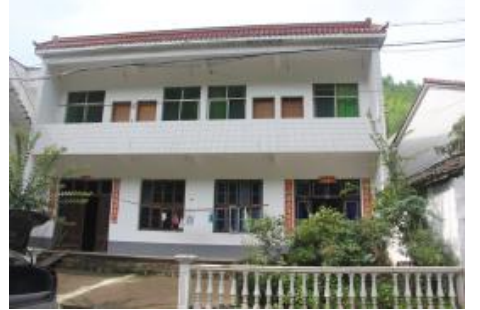

(b)

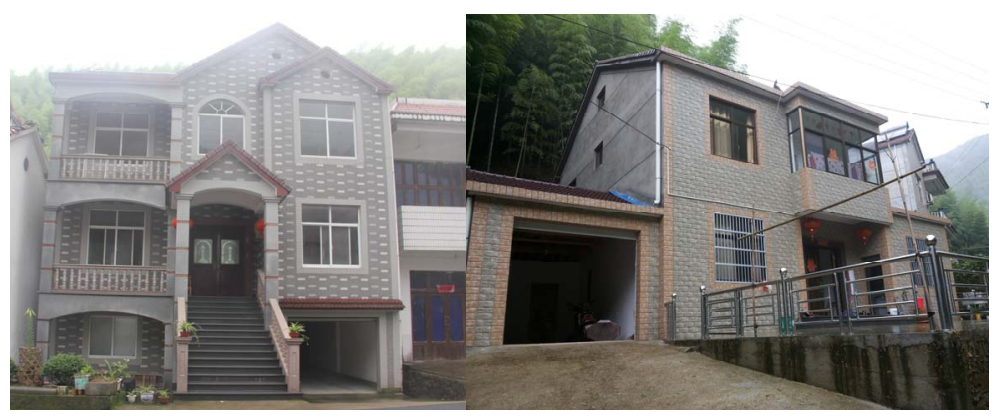

(c)

(d)

Figure 5. Typical buildings built in different periods. (a) Built in early 1980s; (b) Built in 1980s and 1990s; (c) Built after 2000s; (d) Built after 2000s. 
Table 2. Household income.

\begin{tabular}{cccccc}
\hline Household annual income & $\leq \$ 5000$ & $\$ 5,000-\$ 10,000$ & $\$ 10,000-\$ 15,000$ & $\$ 15,000-\$ 20,000$ & $\geq \$ 20,000$ \\
\hline Percentage $(\mathrm{n}=47)$ & $4 \%$ & $13 \%$ & $49 \%$ & $30 \%$ & $4 \%$ \\
\hline
\end{tabular}

room, kitchen are on the first floor, bedrooms are on the second floor except the bedroom for elders. $90 \%$ rural buildings are for self-occupation, the other $10 \%$ are used for both living and business. The proportion of residential and commercial mixed buildings is still growing (Figure 5).

\subsubsection{Floor Area}

We calculated building area of each rural house according to Ligeng village plan and field measurement. The affiliated area, which was affiliated to the main building just for storing fire-woods or odds and ends that people always don't use it, was not calculated (Figure 6). The average floor area was $100.8 \mathrm{~m}^{2}$, the average total building area was $199.5 \mathrm{~m}^{2}$, and the building area per capita is $48 \mathrm{~m}^{2}$. Due to the high ratio of migrant population, the building area per capita was up to $104.5 \mathrm{~m}^{2}$. Because most of the permanent population are elders, the frequently used space was concentrated on the first floor, which was accounted for $60 \%$ (Figure 6).

\subsubsection{Shape Coefficient Window to Wall Area Ratio}

The shape coefficient of rural buildings is high, which is between $0.5-0.8$, the average shape coefficient is 0.70 . The window to wall ratio is small, between $0.06-0.17$ with the average ratio of 0.10 . The ratio of east and west orientation is lower than north and south. The average window to wall ratio is 0.07 and 0.06 , the north and south is 0.13 (Figure 6).

\subsubsection{Building Structure Building Envelope Thermal Bridge}

There are brick-wood structure, brick-concrete structure and frame structure, respectively accounting for $2 \%$, $94 \%$ and $4 \%$. Because the material and construction of the building envelopes in different periods are quite different, the thermal performance of the envelopes are quite different too. The external walls were built up with rammed earth before early 1980s. After then, solid clay bricks took place and became the main wall material till now. Since 2000, the government announced to ban solid clay bricks in order to protecting cultivated land, and to spread new wall materials. Small-sized hollow concrete blocks, steam curing aerated concrete blocks, fired perforated bricks and so on, were used in rural buildings. The thermal bridge is quite different from different structures. The ratio of thermal bridge in rammed earth buildings and brick-concrete structure buildings built in 1980 s to 1990 s is about $10 \%$ to $15 \%$, which is lower than the frame structure buildings built after 2000 , with the ratio of $15 \%$ to $25 \%$ (Figure 7 ).

\subsection{Household Appliances}

Main appliances per household, power, energy efficiency label (EEL), etc. are shown as Figure 8 and Table 3. Refrigeration equipments include electric fan and air conditioner. Average household electric fan is 2.73 units, and air conditioner is 1.18 units. Heating equipments include heater and electric blanket, the average household is 0.84 units and 0.92 units. The lower frequency used, the lower energy efficiency label, such as air conditioner and solar water heater. The higher frequency used, the higher energy efficiency label, such as refrigerator, washing machine and rice cooker. Figure 9 shows the schedule of household appliances used.

\subsection{Occupants' Activities}

There are three typical period of time among a year in Ligeng village: normal times, farming season (in April) and Holidays. Figure 10 shows the ratio of population at home to the total family population (H-F ratio) in 24 hours. Although, the activity of permanent population who lives in villages is not as fixed as people work in cities, however, their habits also have a relatively fixed schedule. April is the season of harvesting tea and bamboo. Because of far distance, farmers take lunch with them. As a result, the average H-F ratio from 6:30 to 4:00 is very low, only $5 \%$. In holidays, the migration workers are back home. In our survey, we found that a small portion family working outside almost the whole year, only went back home for Spring Festival holiday. 


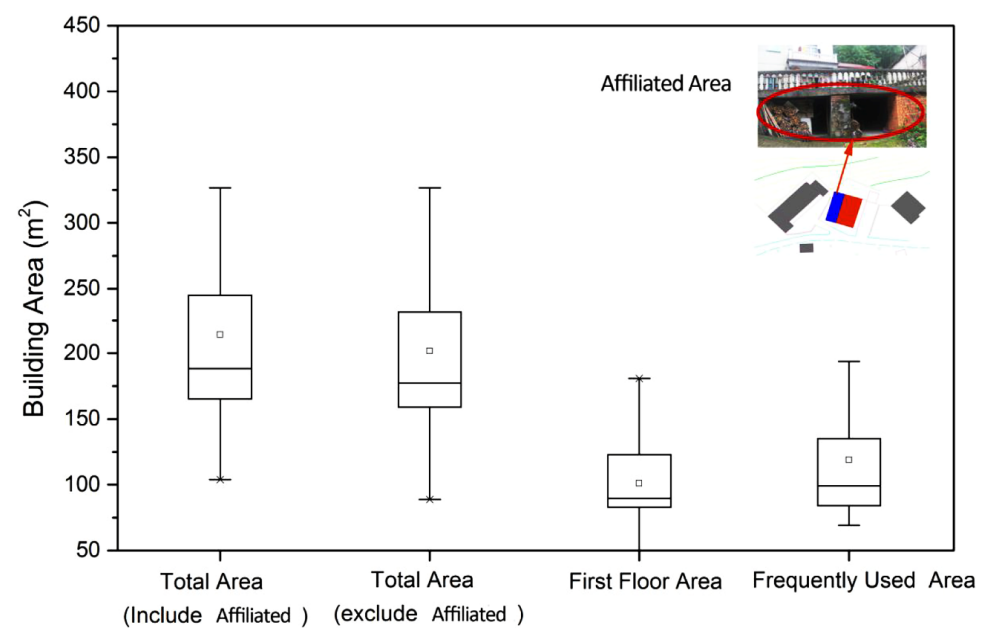

Figure 6. Total building area, floor area and frequently used area.

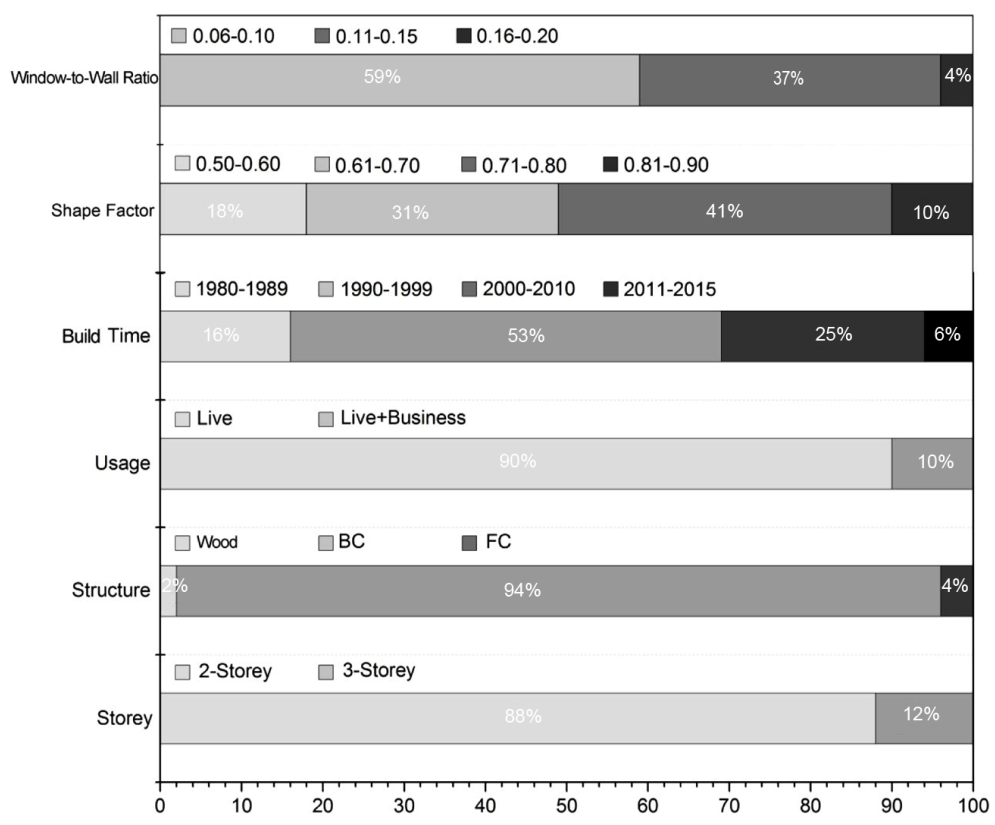

(\%)

Figure 7. Fundamental state about rural buildings.

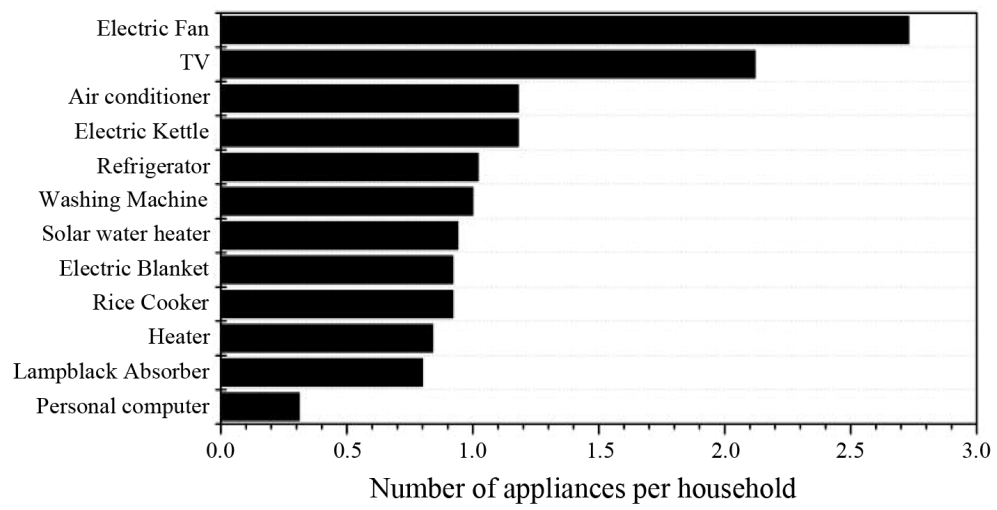

Figure 8. Average household appliances. 


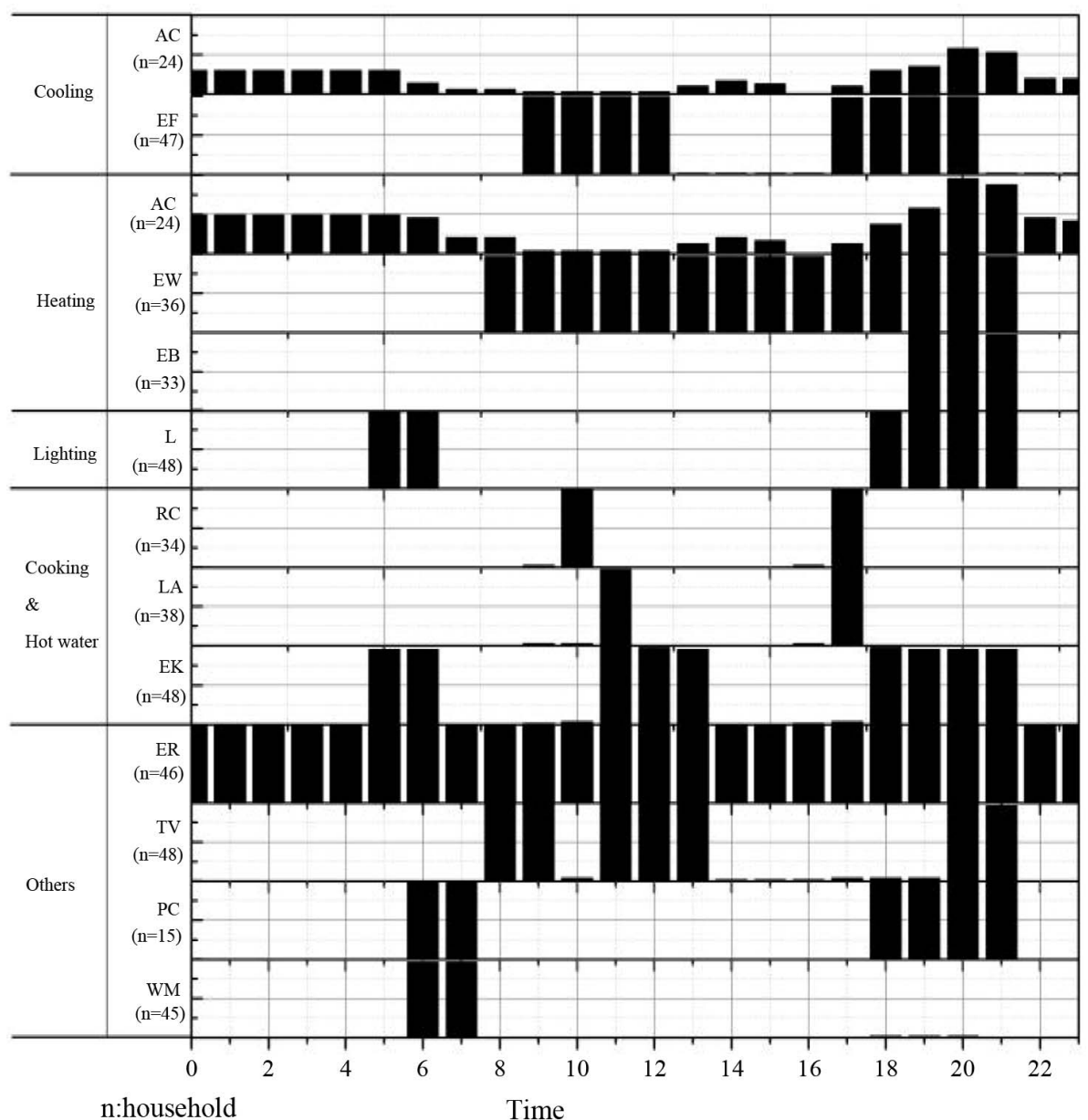

Figure 9. Schedule of household appliances.

Table 3. Power and energy efficiency label (EEL) of household appliances.

\begin{tabular}{cccc}
\hline Type & Appliance & Power & EEL \\
Cooling & Air conditioner & $1100 \mathrm{~W}$ & $3 / 5$ \\
Lighting & Electric fan & $50 \mathrm{~W}$ & - \\
& Energy saving bulb & $50 \mathrm{~W}$ & $2 / 5$ \\
Rice cooker & $900 \mathrm{~W}$ & \\
Looking \& Hot water & Air conditioner & $250 \mathrm{~W}$ & \\
& Electric fan & $1500 \mathrm{~W}$ & $3 / 5$ \\
Air conditioner & $1500 \mathrm{~W}$ & - \\
Heating & Heater & $1100 \mathrm{~W}$ & $1 / 5$ \\
& Electric blanket & $1800 \mathrm{~W}$ & $100 \mathrm{~W}$ \\
Household appliance & Washing machine & $0.5 \mathrm{kwh} / 24 \mathrm{~h}$ & $2 / 5$ \\
& TV & $0.12 \mathrm{kwh} / \mathrm{circle}$ & - \\
\hline
\end{tabular}




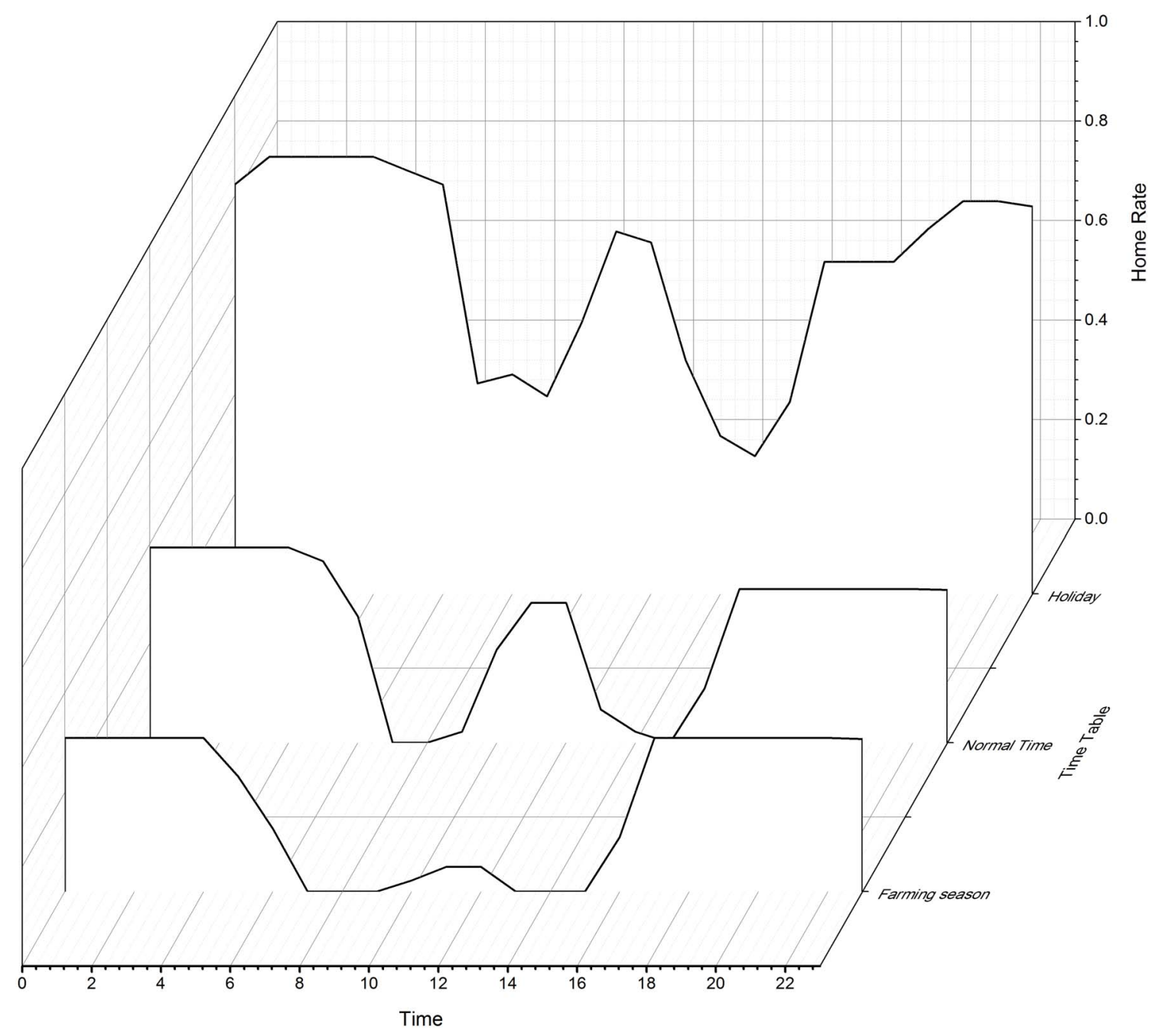

Figure 10. Schedule of human activity.

\subsection{Household Energy Consumption}

At present, according to the energy type used in rural buildings, there are four categories as follows: Electricity, LPG, firewood and solar energy. In addition, there are a very few farmers to use briquettes, which are not included in the statistics. Power supply bureau provided the total electricity consumption per year of the surveyed family from 2010 to 2014, and the electricity consumption per month from July 2014 to June 2015, according to number of electric meter. It shows that the total electricity consumption per year from 2010 to 2014 was on the rise, especially after 2011, the grow was more significant. It was calculated that the energy consumption in Ligeng village was only $6 \mathrm{kWh} /\left(\mathrm{m}^{2} \cdot \mathrm{a}\right)$ (Figure 11). From July 2014 to June 2015, the average monthly household electricity consumption is $116 \mathrm{kWh}$. Figure 12 shows that there were two peak periods of electricity consumption: in January, February and March which was heating period, the average monthly electricity consumption was $149.2 \mathrm{kWh}$; in August and September which was cooling period, the average monthly electricity consumption was $121.4 \mathrm{kWh}$. The maximum power consumption was in March, when is in the Chinese New Year holiday. Obviously, the electricity consumption in heating and cooling period was not balanced, the winter heating period consumption was significantly higher than the summer cooling consumption. In transition season, the consumption in spring (April, May, June, July) was lower than autumn (October, November and December).

LPG is carried in tanks, and the weight of gas is about $14 \mathrm{~kg}$ per carton. The average household using of LPG is about 1.5 barrels per year. Ligeng village is in the mountainous area, where is convenient to get firewood. Therefore, firewood remains one of the most important energy resource for cooking and heat water, with the 


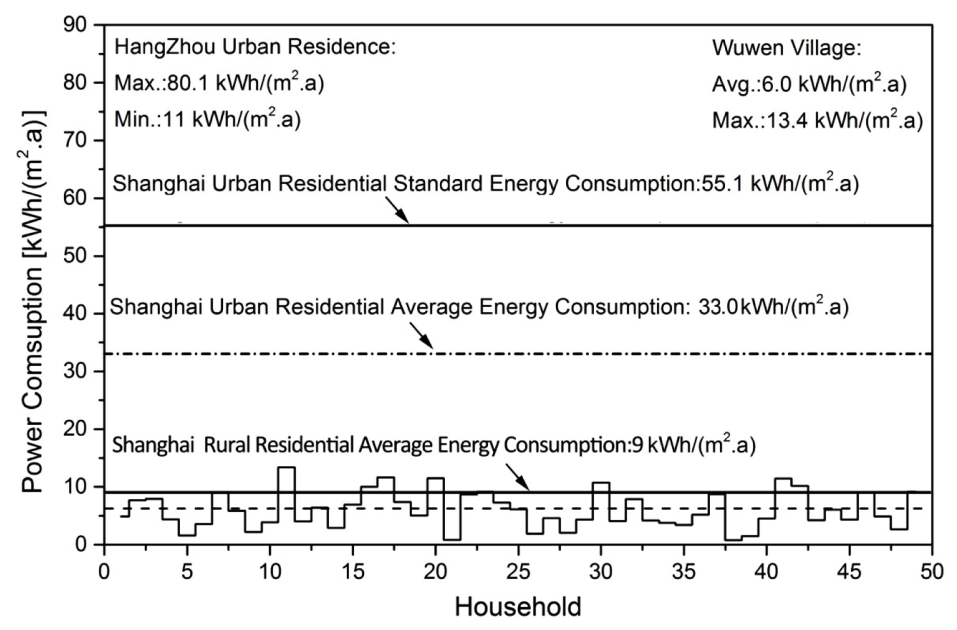

Figure 11. Comparison of building energy consumption between Ligeng village and other surveys.

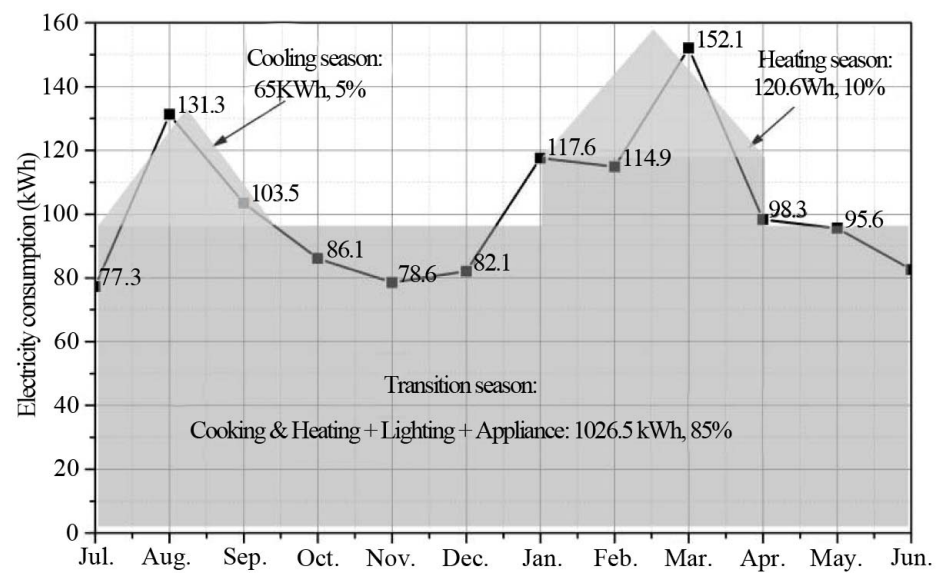

Figure 12. Energy consumption of heating, cooling and daily life (from July 2014 to June 2015).

usage of 1.78 tons per year. Moreover, solar water heater is widely used in local mainly to provide domestic water and shower. Most households answered that in summer, the solar water heater can meet the requirements of daily shower; but electric water heater is also needed in winter besides the solar hot water. The amount of LPG, firewood and solar energy is estimated according to the questionnaire statistics.

\section{Building Energy Consumption}

\subsection{Household Energy Consumption}

Different types of energy obtained from the survey, are converted according to the average low calorific value of the different fuel (Table 4). It was calculated that the energy consumption came from firewood was about 29.5 GJ, accounting for $83 \%$; electricity was $4.2 \mathrm{GJ}$, accounting for $12 \%$; LPG was $1.02 \mathrm{GJ}$, accounting for $3 \%$. The usage of hot water for shower was difficult to survey. We supposed the flew rate of water flower was $0.04 \mathrm{~L} / \mathrm{s}$ [26], and people took shower 3 times a week, 15 minutes each time. According to the questionnaire, electric water heaters were mainly used in winter. In the calculation, we supposed the total amount of heat supplied by the solar energy was $75 \%$. So we can get the solar energy was 0.95 GJ, accounting for $2 \%$.

\subsection{Final Energy Consumption}

Final energy consumption included heating, cooling, lighting, cooking and hot water, household appliances 
(Figure 13). Each type of energy, power equipment was shown in Figure 13. Firewood, LPG and solar energy were for cooking and hot water. Electricity accounted for $12 \%$, which covered five aspects of the final energy consumption of the country, was the most difficult part to be distributed.

Since the usage time of appliances was from respondents' estimation, and we didn't consider the impact of the depreciation of appliances, the exact proportion of hard statistics. It was difficult to get a precise proportion. Two methods were used to estimate the energy consumption.

Method one: Estimated from seasonal feature of the heating and cooling. As shown in Figure 12, the peak periods of summer and winter were mainly due to cooling and heating, which respectively took up $5 \%$ and $10 \%$. Transition season accounted for $85 \%$.

However, this method has two limitations. First, be merely able to divide heating, cooling and the daily life energy consumption. However, cannot be further subdivided the proportion of lighting, cooking and hot water, household appliances. Second, heating and cooling seasons happen to be the Summer holiday and the Spring Festival holiday in China, the P-F rate was higher than normal time. Therefore, the ratio of the actual energy consumption of cooling and heating would be smaller, the proportion of household energy use in daily life would be higher.

Method two: Based on the information obtained from field investigation — number of appliances per household, power, using time and using probability. It was found out that in the absence of heating and cooling

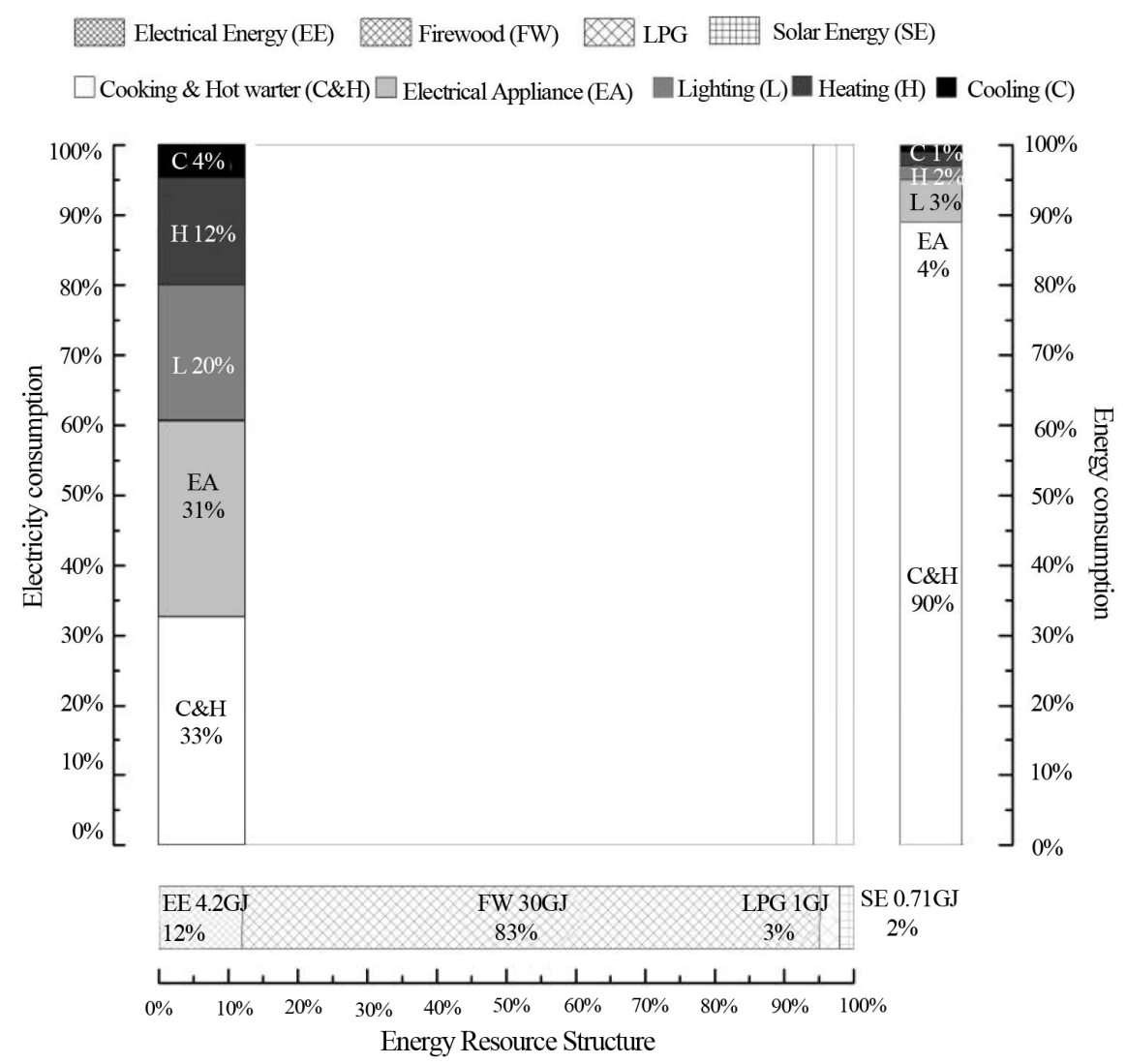

Figure 13. Energy resource structure and energy consumption.

Table 4. Conversion factors from physical unit to coal equivalent [1].

\begin{tabular}{cc}
\hline Energy & Average Low Calorific Value \\
\hline Electricity & $3600 \mathrm{KJ} / \mathrm{kWh}$ \\
LPG & $50,179 \mathrm{KJ} / \mathrm{kg}$ \\
Firewood & $16,726 \mathrm{KJ} / \mathrm{kg}$ \\
\hline
\end{tabular}


conditions, the temperature below $30^{\circ} \mathrm{C}$ in summer and higher than $8^{\circ} \mathrm{C}$ in winter in hot summer and cold winter area, most people think the indoor environment is bearable [8]. There is about $5^{\circ} \mathrm{C}$ temperature difference between indoor and outdoor. According to the typical meteorological year in Huzhou area, outdoor temperature which exceeds $35^{\circ} \mathrm{C}$ was totally about 15 days, and outdoor temperature below $5^{\circ} \mathrm{C}$ was totally about 15 days too. They are taken as the running days of air-conditioner, electric blanket and heater. Running time per day is counted by questionnaires. The using time of appliances such as TV, refrigerator, rice cooker and washing machine are relatively clear, and it would be determined in accordance with a higher probability of the emergence time (Figure 9). In the estimation process, we took no account of equipment depreciation. The total electricity consumption obtained by this method was larger than actual consumption. This is because of the survey error and the running time of appliances. By this method, in total electricity consumption, cooking and hot-water accounted for $33 \%$, household appliances $31 \%$, lighting $20 \%$, heating $12 \%$ and cooling $4 \%$. The heating, cooling and daily life electricity consumption calculated by the two methods are close (Figure 13).

From the energy resource types, energy consumption of cooling and hot water was $90 \%$, household was $4 \%$, lighting was $3 \%$, heating was $2 \%$, cooling was $1 \%$ (Figure 13 ).

\subsection{Comparison with Other Surveys}

According to statistical data in relevant statistical yearbooks [1]-[3], in commercial energy and non-commercial energy consumption in Zhejiang rural area in 2013, coal accounted for 1\%, LPG accounted for 9\% and electricity consumption accounted for $11 \%$, non-commercial energy consumption was $79 \%, 47.5 \mathrm{GJ} /$ per household/year and $15.5 \mathrm{GJ} /$ per capita/year (Figure 14). The building energy consumption in our surveyed village, LPG accounted for $3 \%$, electricity consumption accounted for $12 \%$, firewood was $85 \%, 35.7 \mathrm{GJ} /$ per household/year and $7.32 \mathrm{GJ} /$ per capita/year. Due to the large migrant proportion, if we calculated according to the permanent population, it was 16.8 GJ per capita/year, which was slightly higher than the per capita consumption of Statistical Yearbook. By comparison, we can find that the proportion of electricity was close to the data of Statistical Yearbooks, but the difference of LPG and firewood were a slightly large. The main reason was that Ligeng village was far away from Cities, LPG were tanked which was expensive and not convenient to send. However, the rich vegetation resources in the mountain area provide ample firewood.

From July 2014 to June 2015 , the electricity consumption was only $6 \mathrm{kWh} /\left(\mathrm{m}^{2} \cdot \mathrm{a}\right)$. Sun et al. undertook a similar survey in Shanghai rural area in 2010. The electricity consumption was $9.0 \mathrm{kWh} /\left(\mathrm{m}^{2} \cdot \mathrm{a}\right)$ [22]. In Shanghai rural area, the commercial energy usage has been reached to $90 \%$ in 2007 [28]. However, the electricity consumption was slightly higher than Ligeng village. This shows that the level of rural power consumption in the developed regions is relatively low. Zhu et al. surveyed 18 households urban residential electricity consumption in Hangzhou, the min. was $11 \mathrm{kWh} /\left(\mathrm{m}^{2} \cdot \mathrm{a}\right)$ and the max. was $80.1 \mathrm{kWh} /\left(\mathrm{m}^{2} \cdot \mathrm{a}\right)$ [29]. Jiang et al. investigated 1000 urban residential households electricity consumption in Shanghai, the results showed that the average electricity consumption was $33 \mathrm{kWh} /\left(\mathrm{m}^{2} \cdot \mathrm{a}\right)$, and cooling and heating energy consumption accounted for $10-20 \mathrm{kWh} /\left(\mathrm{m}^{2} \cdot \mathrm{a}\right)$ [30]. In the domestic and foreign studies, the research on the final energy consumption structure in rural area is lesser than urban. Ning et al. from the macroscopic view, and based on the statistical data of energy consumption of urban residents in China, they analyzed the characteristics of energy consumption of residential buildings from 1995 to 2010, and calculated the urban residential energy consumption was $5.59 \mathrm{GJ} /$ per capita, with heating accounting for $25 \%$, cooking and hot water $56 \%$, household appliance $10 \%$, cooling $6 \%$ and lighting

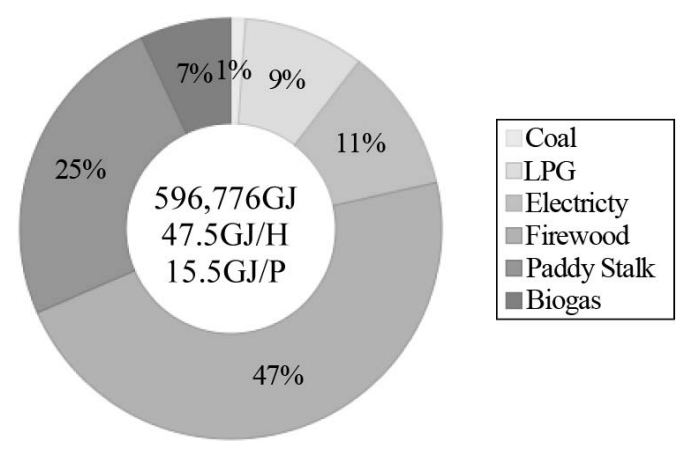

Figure 14. Energy resource structure in Zhejiang (2013). 
3\% in 2010 [27]. Li et al. selected two residential households and took a measurement of electricity, gas for a year to inspect the energy consumption. Finally, they put forward the results of energy consumption structure of Shanghai: $25 \%-33 \%$ of gas, $11 \%-13 \%$ of scouring bath, $19 \%-21 \%$ of air conditioning, $5 \%-6 \%$ of lighting, $8 \%-10 \%$ of information and entertainment, $10 \%-13 \%$ of refrigerators, and $15 \%-20 \%$ of other appliances. Then they compared with the apartment houses energy consumption measured in 2002-2003 in Okinawa of Kitakyushu, Japan, and they found that energy consumed by each person of Okinawa was 1.424 times as that of Shanghai. From this, it can be seen that the rural building energy consumption in Zhejiang province is lower than urban residents, and far less than developed countries.

\section{Analysis of the Influential Factors}

There are many factors determining energy consumption in rural areas. Factors associated with buildings include shape coefficient, window to wall ratio and per capita floor area etc. Family-related factors include the permanent population, the population age structure (proportion of the population aged over 50 in the total household members). Appliance factors include the number of air conditioner, etc. These factors will be analyzed as follows:

\subsection{Correlation with Income}

We took the total electricity consumption in 2014 as the independent variable, and the average household income and per capita income as the dependent variable, then analyzed. Figure 15 shows the correlation between total electricity consumption and the average household income, and the total electricity consumption and per capita income, and the determinant factor was 0.0115 and 0.015 , which indicated no apparent correlation. Yutaka et al. surveyed the rural households in the fringes of Xian city, and they reached the same conclusions [16].

\subsection{Correlation with Building Area}

From the actual survey, it was found that there was a large leave unused area in rural buildings, the frequently used area is only $60 \%$ of the total building area. As first step, the correlation between total building area and total electricity consumption was examined. Figure 16 shows the correlation was not correlative, because the determinant factor was only 0.1447 . Secondly correlation between frequently used building area was also examined. The determinant factor was 0.378 and the results showed there was obvious correlation between them (Figure 16). From these results we concluded that total electricity consumption in rural areas appeared no correlation with total area, but had some dramatic correlation with frequently used area.

\subsection{Correlation with Building Shape Coefficient and Window to Wall Ratio}

Building shape coefficient and window to wall ratio are related to heating and cooling energy consumption.

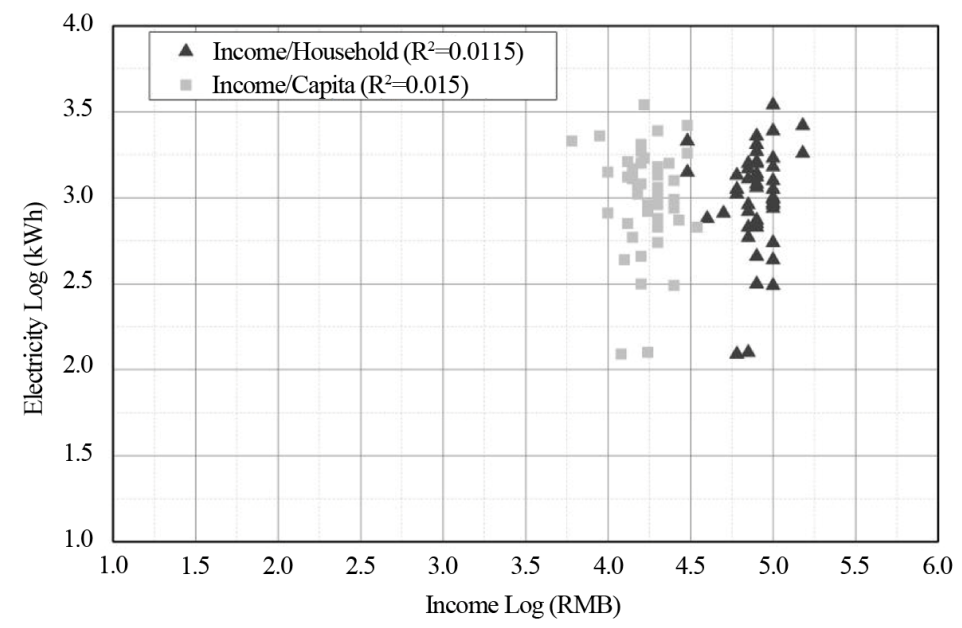

Figure 15. Correlation between income and electricity consumption. 


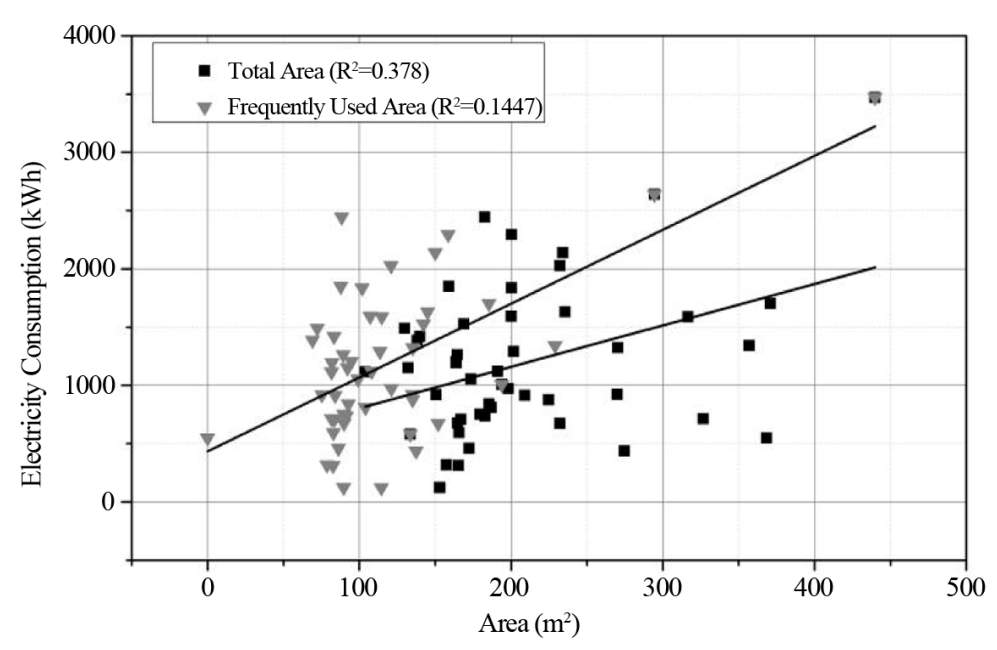

Figure 16. Correlation between total building area, frequent used area and electricity consumption per year.

Figure 17 shows that the correlation was not obvious, with determinant factor of 0.0228 and 0.0932 . The reason is that only parts of the rural buildings adopted heating and cooling appliances in South rural area in China, coupled with a small proportion of the frequently used area, which led to no correlation with them. It indicated that in the energy-saving design of rural buildings in the southern region, it may be appropriate to relax the building shape coefficient and window to wall ratio requirements.

\subsection{Correlation with Number of Air Conditioner}

The number per household of appliances, such as refrigerator, TV and so on, were very close except air conditioner. The correlation between the number of air conditioner per household was examined, and the determinant factor was 0.4966 (Figure 18). The result showed an obvious correlation between them. However, from the survey, we found that the energy efficiency label of air conditioner in Ligeng village was low, most of them were three level which was the lowest. So the villagers should be encouraged to buy energy-saving air conditioners.

\subsection{Correlation with Building Function}

At present, there were several families deal in "agritainment", shops and agro-product processing. We chose those families, which has similar total building area, family size and permanent population, then divided into two groups according to different building functions: one group was just for living, the other group was for living and business (Table 5). Then the two groups were compared about the electric energy consumption per month. Figure 19 shows that the electric energy consumption of the two groups were very close from November 2014 to April 2015. From July 2014 to October 2014, May and June in 2015, "L + B" group was about 48\% higher than "L" Group, which was caused by village tourism.

\section{Conclusions}

The study investigated the rural energy consumption and the influential factors by taking Ligeng village as a model. From this study, the following conclusions are reached:

1) Ligeng village belongs to relatively wealthy village in Zhejiang Province; the electric energy consumption was $6 \mathrm{kWh} /\left(\mathrm{m}^{2} \cdot \mathrm{a}\right)$, which was far less than urban residential household. Compared with the rural buildings around Shanghai, the ratio of commercial energy consumption was very high (above 90\%), and the electricity consumption was close $\left(9 \mathrm{kWh} /\left(\mathrm{m}^{2} \cdot \mathrm{a}\right)\right.$ to Shanghai rural buildings $)$.

2) From energy consumption structure, the ratio of non-commercial energy consumption is higher than commercial energy consumption. Firewood accounted for $83 \%$, electricity for $12 \%$, LPG for $3 \%$ and solar energy for $2 \%$. 


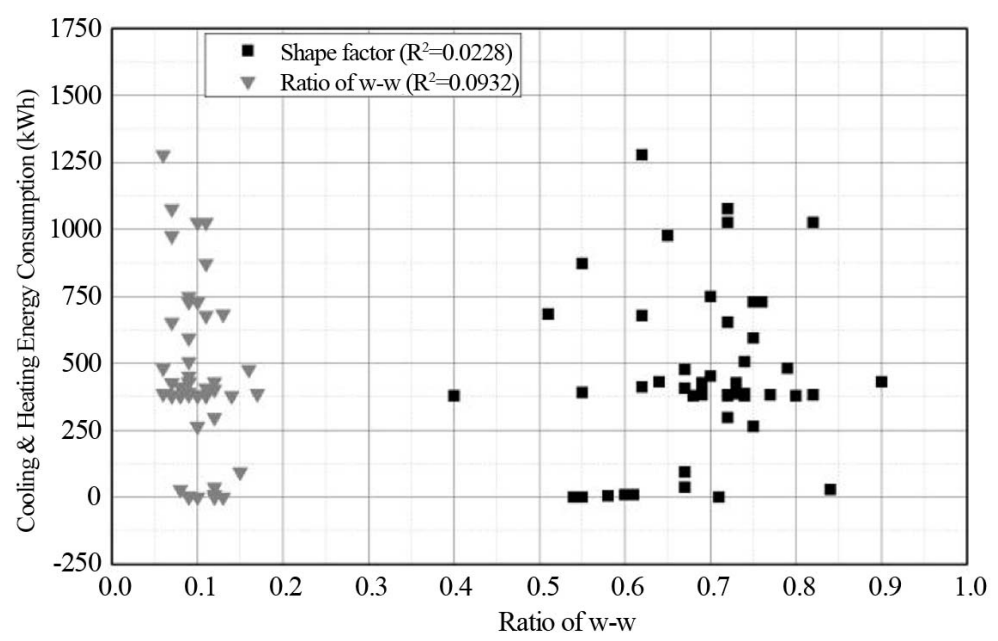

Figure 17. Correlation between cooling and heating energy consumption and building shape factor and ratio of $\mathrm{w}-\mathrm{w}$.

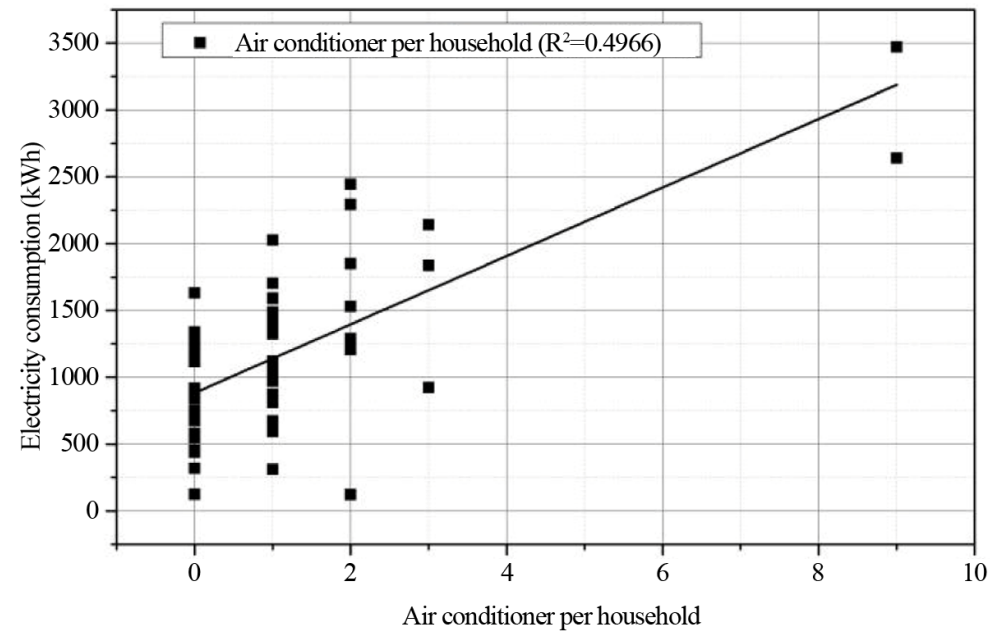

Figure 18. Correlation between electricity consumption and air conditioner per captia.

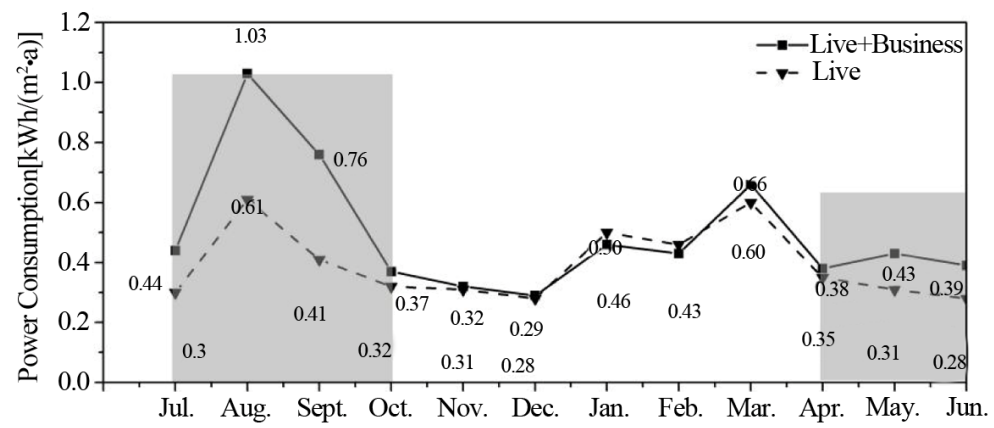

Figure 19. Power consumption compare between " $\mathrm{L}+\mathrm{B}$ " group and "L" group.

3) At present, rural building energy consumption is still mainly to meet the basic daily needs. Energy consumption of cooking and hot water and household appliances are higher than others, respectively accounting for $33 \%$ and $31 \%$, lighting for $20 \%$, heating for $12 \%$, and cooling for $4 \%$.

4) Correlation analysis shows that frequently used area, and number of air-conditioner per household have 
Table 5. "L + B" group and "L" group.

\begin{tabular}{ccccc}
\hline Group & Family Number & Total Building Area $\left(\mathrm{m}^{2}\right)$ & Family Size & Permanent Population \\
\hline L+B & $7,10,14,24,32$ & $250-400$ & $4-6$ & 2 \\
L & $9,23,27,35,37,40$ & $250-400$ & $4-6$ & 2 \\
\hline
\end{tabular}

obvious correlation with the energy consumption, and the correlation is not obvious with income, total building area, building shape coefficient and window to wall ratio. The building function has a greater impact on energy consumption. "L + B" group was about $48 \%$ higher than "L" Group, which was caused by village tourism.

To sum up the above arguments, the rural building energy consumption is low at present. However, the low energy consumption comes at the cost of uncomfortable and low economic activities. With the adjustment of rural industrial structure and the improvement farmers' living standard, rural building energy consumption will face tremendous pressure in the future.

\section{Acknowledgements}

The research was cooperated by the University of Kitakyushu (Japan) and Zhejiang University (China) and financially sponsored by the National Natural Science Foundation of China (Subject number: 51238011).

\section{References}

[1] State Statistical Bureau, China (2013) China Energy Statistical Yearbook (2013-2000). China Statistical Publishing House, Beijing.

[2] Zhejiang Statistical Bureau, China (2013) Zhejiang Statistical Yearbook (2013-2000). China Statistical Publishing House, Beijing.

[3] Zhejiang Statistical Bureau, China (2013) Zhejiang Natural Resource and Statistical Yearbook on Environment (2013-2000). China Statistical Publishing House, Beijing.

[4] Wang, X.H. (1994) Situation and Development of Rural Household Energy Consumption in China. Journal of Nanjing Agricultural University, 17, 134-141.

[5] He, B.J., Yang, L., Ye, M., Mou, B. and Zhou, Y.N. (2014) Over View of Rural Building Energy Efficiency in China. Energy Policy, 69, 385-396. http://dx.doi.org/10.1016/j.enpol.2014.03.018

[6] Luo, G.L. and Zhang, Y.M. (2008) Analysis on Rural Energy Consumption of China. Chinese Agricultural Science Bulletin, 24, 535-540.

[7] Wang, X.H. and Feng, Z.M. (2001) Study on Rural Household Energy Consumption in China: Consumption Level and Affecting Factors. Transactions of the CSAE, 17, 88-91.

[8] Guo, B.L. and Wang, Y.J. (2002) Present Situation and Prospects of China Residential Energy Consumption. Rural Energy, 105, 4-7.

[9] Energy Conservation Research Center of Tsinghua University (2013) 2012 Annual Report on China Building Energy Efficiency. China Building Industry Press, Beijing.

[10] Wang, X.H., Hao, X.R. and Jin, L. (2014) Study on Rural Household Energy Consumption in China Based on Household Investigation from Typical Counties. Transactions of the Chinese Society of Agricultural Engineering (Transactions of the CSAE), 30, 206-212.

[11] Ning, X.Y., Zhang, X. and Gao, J. (2013) Analysis of Status Quo and Influencing Factors of Domestic Energy Consumption by Typical Villages and Towns in Different Climatic Regions. Building Science, 29, 98-102.

[12] Wang, P., Liu, Q. and Qi, Y. (2014) Factors Influencing Sustainable Consumption Behaviors: A Survey of the Rural Residents in China. Journal of Cleaner Production, 63, 152-165. http://dx.doi.org/10.1016/j.jclepro.2013.05.007

[13] Wang, X.H. and Hu, X.Y. (2010) Factors Influencing Rural Household Energy Consumption. Transactions of the CSAE, 26, 294-297.

[14] Zhu, L. (2014) Analysis of Residential Energy Utilization and Behavior Patterns in Hangzhou. Zhejiang University, Hangzhou.

[15] Li, X., Lin, C., Wang, Y., Zhao, L.Y., Duan, N. and Wu, X.D. (2015) Analysis of Rural Household Energy Consumption and Renewable Energy Systems in Zhangziying Town of Beijing. Ecological Modelling, 318, 184-193. http://dx.doi.org/10.1016/j.ecolmodel.2015.05.011

[16] Tonooka, Y., Liu, J.P., Kondou, Y., Ning, Y.D. and Fukasawa, O. (2006) A Survey on Energy Consumption in Rural 
Households in the Fringes of Xian City. Energy and Buildings, 38, 1335-1342. http://dx.doi.org/10.1016/j.enbuild.2006.04.011

[17] Wu, Y.J., Xu, D. and Wang, X.Y. (2010) Investigation on Energy Efficiency of Rural Residential Housing in Jinzhou Area. Journal of Liaoning Technical University (Natural Science), 29, 228-231.

[18] Yao, C.S., Chen, C.Y. and Li, M. (2012) Analysis of Rural Residential Energy Consumption and Corresponding Carbon Emissions in China. Energy Policy, 41, 445-450. http://dx.doi.org/10.1016/j.enpol.2011.11.005

[19] Liu, W.L., Spaargaren, G., Heerink, N., Mol, A.P.J. and Wang, C. (2013) Energy Consumption Practices of Rural Households in North China: Basic Characteristics and Potential for Low Carbon Development. Energy Policy, 55, 128138. http://dx.doi.org/10.1016/j.enpol.2012.11.031

[20] Niu, H.W., He, Y.Q., Desideri, U., Zhang, P.D., Qin, H.Y. and Wang, S.J. (2014) Rural Household Energy Consumption and Its Implications for Eco-Environments in NW China: A Case Study. Renewable Energy, 65, 137-145. http://dx.doi.org/10.1016/j.renene.2013.07.045

[21] Shan, M., Wang, P.S., Li, J.R., Yue, G.X. and Yang, X.D. (2015) Energy and Environment in Chinese Rural Buildings: Situations, Challenges, and Intervention Strategies. Building and Environment, 91, 271-282. http://dx.doi.org/10.1016/j.buildenv.2015.03.016

[22] Sun, Y.-L., Lin, Z.-P. and Wang, X.-M. (2011) An Investigation of Envelope Situation and Simulation of Heating/ Cooling Energy Consumption for Rural Residential Buildings in Shanghai. Building Science, 27, 38-70.

[23] Li, Z.H., Sun, J. and Hiroshi, Y. (2009) Field Measurement and Analysis of the Residential Energy Consumption Structure of Shanghai. Journal of Tongji University (Natural Science), 37, 384-389.

[24] Zhou, X.H., Zhou, X.Q. and Ma, J.L. (2011) Investigation on Energy Consumption and Analysis on Energy-Saving Potential of Rural Residential Buildings in Guangdong. Building Science, 27, 44-47.

[25] Anji Statistical Bureau P.R. China (2013) Anji Statistical Yearbook. China Statistical Publishing House. http://www.ajtj.gov.cn/tjnj/2013/

[26] China's Urban and Rural Areas and Housing Construction Department (2012) Minimum Allowable Values of Water Efficiency and Water Efficiency Grades for Shower (GB28378-2012). China Building Industry Press, Beijing.

[27] Ning, Y.D., Cai, J.Y. and Ding, T. (2013) Urban Household Energy Consumption Structure in China. Journal of Beijing Institute of Technology (Social Science Edition), 15, 26-33.

[28] Energy Conservation Research Center of Tsinghua University (2013) 2012 Annual Report on China Building Energy Efficiency. China Building Industry Press, Beijing.

[29] Li, Z. (2014) Analysis of Residential Energy Utilization and Behavior Patterns in Hangzhou. Zhejiang University, Hangzhou.

[30] Li, Z.H., Sun, J. and Hiroshi, Y. (2009) Field Measurement and Analysis of the Residential Energy Consumption Structure of Shanghai. Journal of Tongji University (Natural Science), 37, 384-389. 